\title{
GRØNNERE TEKSTILER PÅ HOSPITALER
}

Guide til grønne indkøb i sundhedssektoren

(10) Nordisk

Ministerråd 


\section{Grønnere tekstiler på hospitaler}

Guide til grønne indkøb i sundhedssektoren

David Watson, PlanMiljø

Rikke Fisher-Bogason; PlanMiljø

ISBN 978-92-893-5058-7 (PRINT)

ISBN 978-92-893-5059-4 (PDF)

ISBN 978-92-893-5060-O (EPUB)

http://dx.doi.org/10.6027/ANP2017-740

ANP 2017:740

๔ Nordisk Ministerråd 2017

Layout: Gitte Wejnold

Omslagsfoto: Pexels.com

Foto: Scanpix.dk

www.norden.org/nordpub

Download nordiske publikationer: www.norden.org/nordpub

\section{Det nordiske samarbejde}

Det nordiske samarbejde er en af verdens mest omfattende regionale samarbejdsformer. Samarbejdet omfatter Danmark, Finland, Island, Norge og Sverige samt Færøerne, Grønland og Åland.

Det nordiske samarbejde er både politisk, økonomisk og kultu-relt forankret, og er en vigtig medspiller i det europæiske og internationale samarbejde. Det nordiske fællesskab arbejder for et stærkt Norden i et stærkt Europa.

Det nordiske samarbejde ønsker at styrke nordiske og regiona-le interesser og værdier i en global omverden. Fælles værdier landene imellem er med til at styrke Nordens position som en af verdens mest innovative og konkurrencedygtige regioner.

Nordisk Ministerråd

Ved Stranden 18

1061 København K

www.norden.org 


\section{GRØNNERE TEKSTILER PÅ HOSPITALER}

Guide til grønne indkøb i sundhedssektoren 


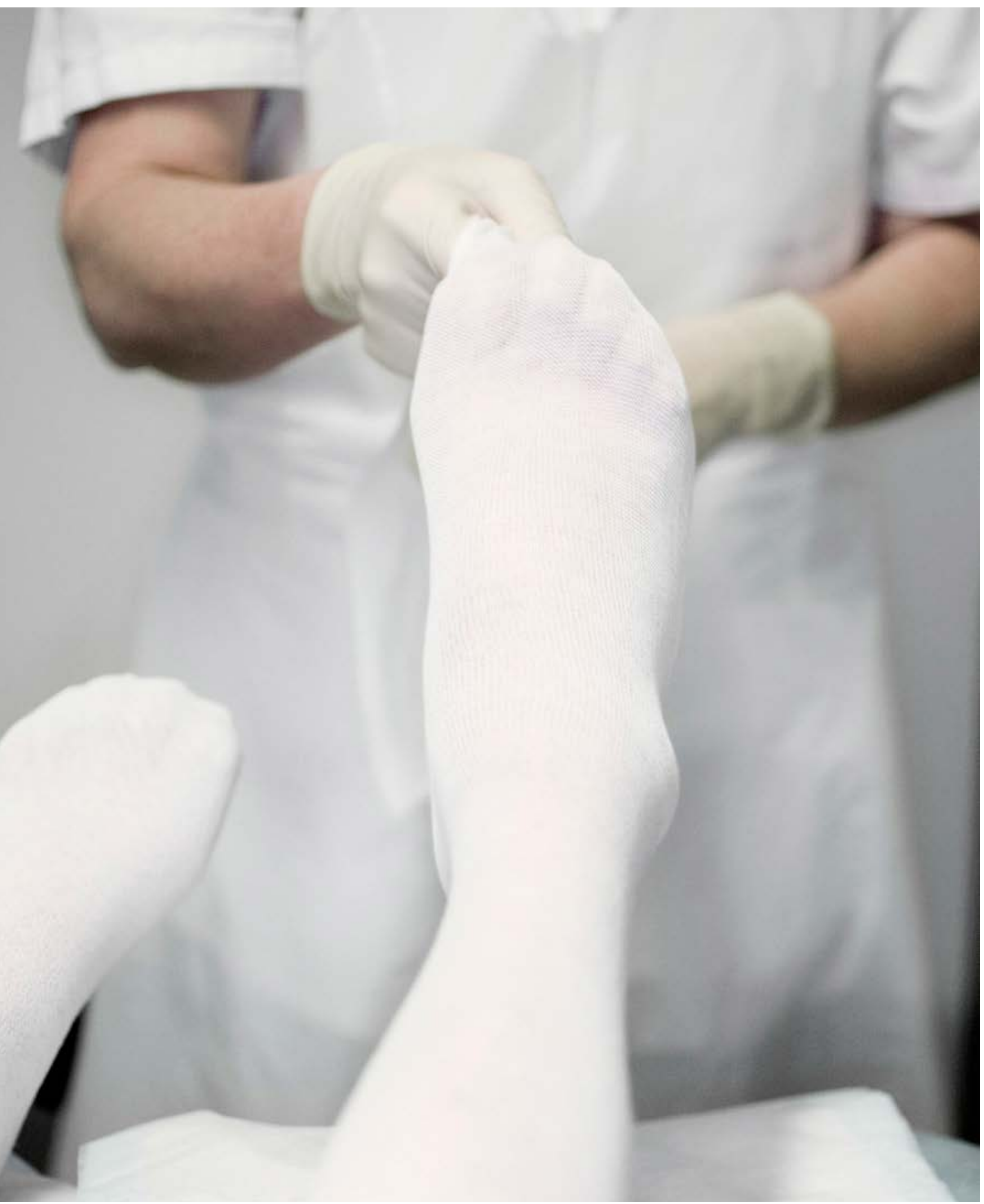




\section{INDHOLD}

6 Sådan bruges denne guide

8 Afsnit 1

De vigtigste aspekter man skal være opmærksom på

10 Afsnit 2

Indkøbsproces, markedsdialog og innovation

15 Afsnit 3

Links til nyttige dokumenter og ressourcer

22 Afsnit 4

Et hurtigt overblik over miljømærker

24 Afsnit 5

Valg af fiber

28 Afsnit 6

Engangs- kontra flergangstekstiler

30 Afsnit 7

Brug totalomkostningerne

33 Afsnit 8

Om guiden og netværket bag 


\section{Sådan bruges denne guide}

Denne guide henvender sig til indkøbere i hospitalssektoren, som planlægger at indkøbe tekstilprodukter og tekstilservices. Guiden hjæ/per dig med at opstille rimelige og gennemførlige miljøkriterier og giver dig grundlæggende oplysninger om, hvad du skal overveje, når du ønsker at mindske de miljømæssige konsekvenser af brugen af tekstiler.

Vejledende dokumenter kan være til stor hjælp og inspiration for indkøbere, som vil udnytte mulighederne ved miljømæssige og sociale forbedringer via offentlige indkøb. I denne guide kan du læse du om de miljømæssige konsekvenser af tekstilindkøb, om eksisterende miljømærker og tilgængelige kriterier, og om de aspekter af tekstilernes livscyklus, der er vigtige at forholde sig til. Det er dog vigtigt, at hver udbudsproces placeres i den kontekst, som gælder for den specifikke organisation og det specifikke produkt, og at indkøberen tager højde for alle organisationsmæssige og brugerrelaterede effekter af de valg, der træffes, når kriterierne fastsættes.

Hygiejnehensyn har altid førsteprioritet ved beslutninger vedrørende tekstiler i sundhedssektoren. Brugerkomfort må heller ikke tilsidesættes. Det er muligt at tage hensyn til begge dele og samtidig mindske miljøbelastningen. 


\section{ET KOMPLEKST INDKøBSLANDSKAB}

Der er mange forskellige modeller for indkøb af tekstiler til sundhedssektoren i de nordiske lande. De kan variere med hensyn til, hvordan indkøbene er organiseret, og hvad der indkøbes.

\section{- Hvordan organiseres indkøbene?}

Det er et kompliceret spørgsmål, som varierer fra land til land og i nogle tilfælde fra region til region. I Danmark har regionerne opstillet en ramme for indkøb, som de enkelte hospitaler bruger til at foretage bestillinger fra dag til dag. I Norge fastsætter en central indkøbsorganisation indkøbsrammer, som de individuelle hospitalsadministrationer kan beslutte, om de vil benytte. Hvis dette ikke er tilfældet, organiserer de deres egne indkøb. I Sverige er strukturen ad hoc med regioner/landsting, der i nogle tilfælde samarbejder om at indgå rammeaftaler om indkøb, men hvor de individuelle hospitaler selv foretager mindre indkøb. Generelt mindsker rammeaftaler bureaukratiet og ressourcebehovet i forbindelse med udbud, og de medvirker til at opnå lavere priser som følge af et større volumen.

\section{- Hvad indkøbes der?}

En typisk rammeaftale vil omfatte en lang række tekstilprodukter fra sengetøj over patientbeklædning til medarbejderuniformer og tekstiler til operationstuer. Alternativt eller i tillæg hertil kan regioner og hospitalsadministrationer indkøbe tekstilservice eller vaskeriservice. Især vaskeriservice indkøbes ofte af de enkelte hospitaler eller grupper af hospitaler, som har indgået aftale med et vaskeri, i stedet for på regionalt eller nationalt niveau. Vaskerierne kan være privatejede, ejet af hospitalsadministrationen, men med et selvstændigt budget, eller de kan være offentligt ejet af et partnerskab af hospitaler og det lokale styre. 
Afsnit 1

\title{
De vigtigste aspekter man skal være opmærksom på
}

\author{
Forbruget af tekstiler står for 4-6 \% af den samlede miljøbelastning forårsaget \\ af det europæiske forbrug ${ }^{1}$. Disse miljømæssige konsekvenser skyldes både \\ produktionen af tekstiler og vask og pleje af disse. For tekstiler til sundhedssektoren, \\ der anvendes mange gange, ligger hovedvægten af miljøbelastningen i brugsfasen, \\ mens den for tekstiler til engangsbrug primært ligger i produktionsfasen.
}

Denne guide fokuserer på grønne indkøb, dvs. hvordan sundhedssektorens indkøbere kan reducere de miljømæssige konsekvenser af deres indkøb. Indkøbere kan dog også være interesserede $\mathrm{i}$ at foretage bæredygtige indkøb, som også omfatter de etiske aspekter, der er forbundet med leveringen af produkterne. Boksen på side 18 indeholder nogle ressourcer, som kan medvirke til at udvikle etiske kriterier.

For at reducere miljøbelastningen er det en god idé at fokusere på begge områder: Valg af de tekstiler, du køber/leaser, og hvordan de bliver vasket (selv om du måske ikke har indflydelse på det sidste). Og det er også vigtigt at være opmærksom på sammenhængen mellem disse områder. Forskellige fibertyper kræver forskellig behandling.

Du kan anskue begge disse områder vafhængigt af, om du køber og ejer tekstilerne og køber vaskeriservice, eller du indkøber fuld tekstilservice inklusive en leasingmodel.

Produktionsbaserede påvirkninger: Mange produktionsbaserede påvirkninger forårsages af brugen af kemikalier og energi i fremstillingen. Derudover kan restprodukter fra nogle af de mange miljøfarlige kemikalier, der anvendes i produktionen, stadig befinde sig i tekstilerne og udgøre en sundhedsrisiko for følsomme brugere.
Disse problemer håndteres fint ved hjælp af forskellige miljømærker, specielt det nordiske svanemærke og EU's miljømærke (også kendt som EU-blomsten) (se afsnit 4, side 22) og af EU's GPPkriterier for tekstiler. De behandles også i forskellige nationale vejledninger for grønne offentlige indkøb (se afsnit 3 , side 19).

Valg af fibertype er vigtigt: Bomuldsproduktion belaster miljøet meget, hvilket især skyldes højt forbrug af pesticider, dyrkningsareal og vand. At vælge økologisk mindsker nogle af disse påvirkninger, men det kan også gøres ved at skifte til andre fibre som $\mathrm{fx}$ polyester. Læs mere om dette i afsnit 5, side 24-25.

En vigtig, men ofte ignoreret, måde at mindske alle produktionsbaserede påvirkninger på er at forlænge produkternes levetid mest muligt. Herved sparer man også penge (se afsnit 7, side 30-31). Som indkøber kan du hjælpe ved 1) at vælge en holdbar fiber (se afsnit 5 , side 24.25), 2) at vælge de farver, der bedst kan tåle at blive vasket og brugt af patienter og personale, 3 ) at opstille kriterier for vaskeriservice, som mindsker belastningen af tekstilerne. Nogle miljømærker (se afsnit 4) angiver kriterier for holdbarhed, og det gør de europæiske standarder (EN) og de nationale standarder for tekstiler ogsåㄹ ${ }^{2}$ men her er der tale om meget basale kriterier. Det er bedre at indhente dokumentation fra leverandører om, hvor mange anvendelser/vaskecyklusser tekstilerne kan modstå.

\footnotetext{
1 EEA (2014) Environmental Indicator Report 2014 http://www.eea.europa.eu/publications/environmental-indicator-report-2014

${ }^{2}$ Se for eksempel internationale og norske standarder udgivet af Norsk Standard https://www.standard.no/no/Nettbutikk/ produktkatalogen/?ProdCat $=11360430$
} 


\section{HOSPITALSLOGOER OG HVORDAN DU UNDGÅR UNØDIGT SPILD}

To situationer kan medføre bortskaffelse af store mængder ellers velfungerende tekstiler i sundhedsvæsenet: 1) skift af servicevirksomhed, som du leaser tekstiler fra,

og 2) rebranding/ændring af logoet for dit hospital, distrikt eller din region.

Der er flere alternative måder til at undgå dette betydelige ressourcespild:

1. Indskriv i kontrakten med tekstilservicevirksomheden, at tekstiler kan tilbagekøbes af hospitalet ved kontraktperiodens afslutning

2. Vælg neutrale mærker på dine tekstiler, som kan benyttes på tværs af sundhedsplejedistrikter, hospitaler osv.

3. Spørg din leverandør, om tekstiler kan mærkes med aftagelige logoer

Påvirkninger i brugsfasen: Hygiejne har selvfølgelig første prioritet ved vask af tekstiler. Men det er muligt at reducere miljøpåvirkningerne af at vaske uden at give køb på hygiejnen. Mulighederne omfatter større vand- og energieffektivitet, brug af grønnere vaskemidler og miljøeffektive logistikløsninger. I nogle lande ( $f x$ Danmark og Norge) tillader hygiejnevejledningen for vaskerier lavere vasketemperaturer, under forudsætning af at der bruges vaskemidler, som har samme steriliserende virkning (se side 16-17)

Det nordiske svanemærke for tekstilservices giver et samlet overblik over potentielle forbedringer. Bemærk dog, at en vaskeriservice, som har det nordiske svanecertifikat, muligvis kun har foretaget de vigtigste miljøforbedringer (få mere at vide i afsnit 4, side 22).
Endelig, og selv om dette ikke omfattes af det nordiske svanemærke, kan fibervalget påvirke miljøeffekterne fra vaskeprocessen (se afsnit 5, side 24).

Valg af affaldshåndteringer ofte også et emne, når der skal træffes miljømæssige beslutninger. At sikre at en tekstilserviceleverandør genanvender deres tekstiler, når de er slidt op, kan give nogle fordele, men det er ikke lige så vigtigt for de generelle miljøpåvirkninger som at forlænge brugsfasen.

En oversigt over miljøpåvirkninger kan findes i baggrundsdokumentet for tekstiler fra Styrelsen for offentlige indkøb i Sverige og denne styrelses baggrundsdokument for tekstilservice samt i EU Joint Research LCA-rapport. 
Afsnit 2

\section{Indkøbsproces, markedsdialog og innovation}

En indkøbsproces kan være kompliceret, og den består af adskillige trin og strategiske beslutninger. Hvis der skal indgå miljøkriterier, skal dette besluttes i den forberedende fase for at sikre, at der stilles de rigtige spørgsmål, og at der træffes beslutninger på det rigtige tidspunkt.

Den første beslutning, der skal træffes, er, om der skal indkøbes produkter eller funktioner. Når produktgruppen er tekstiler, betyder det, at det vil være relevant at overveje, om der skal købes tekstiler eller købes adgang til tekstiler - dvs. om de skal leases.

Leasing af tekstiler kan have en potentiel positiv effekt på miljøbelastningen. Dette skyldes, at ejerskabet til produktet holdes hos leverandøren, som har en økonomisk interesse i at sikre en lang levetid for produktet. Jo længere et produkt kan anvendes, desto mindre er miljøbelastningen og brugen af knappe ressourcer.

Uanset om man beslutter at købe eller at lease tekstiler og tekstilservices, er det vigtigt at undersøge markedet i en forudgående markedsdialog. Det er via markedsdialogen, at du kan få kendskab til de tilgængelige produkter, til deres miljøegenskaber og til andre relevante kvalitetsrelaterede aspekter (se eksemplet på side 11).

Markedsdialogen er en dialog mellem kunden og potentielle leverandører, der gennemføres forud for en formel udbudsproces for at sikre, at udbuddet er realistisk og afspejler, hvad der er tilgængeligt på markedet, men også at det er ambitiøst.
Der er mange måder at gennemføre denne dialog på, men det vigtigste er at huske, at det er tilladt indtil det tidspunkt, hvor udbuddet offentliggøres. Efter offentliggørelsen begrænses dialogen med potentielle leverandører.

Hvilke spørgsmål skal du stille i en markedsdialog? Mange aspekter vil være relevante at overveje, men ud fra et miljøperspektiv skal følgende emner drøftes:

- Tilgængeligheden af miljømærkede produkter

- Tilgængeligheden af økologiske bomuldsbaserede produkter

- Brug af alternative fibre

- Tekstilfiberens oprindelse

- Indhold af genanvendte fibre

- Håndtering af kemikalier, energi og vand $i$ produktionen

- Egenskaber relateret til vask og vedligeholdelse

- Holdbarhed inklusive mulighed for reparation

- Aftagelige logoer

- Farvevalg og miljømæssige konsekvenser

- Muligheder for affaldsbehandling (kan tekstilerne genanvendes?)

Mere inspiration til emner, der kan drøftes med markedet for at klarlægge, hvilke miljøkriterier der kan bruges, kan findes i Europa-Kommissionens baggrundsnote om GPP-kriterier for tekstiler. 


\section{NORSKE SYKEHUSINNKJØP: MARKEDET HJAELPER MED AT OPSTILLE REALISTISKE KRITERIER}

I 2014 indkøbte Sykehusinnkjøp HF (tidligere HINAS) tekstiler til sundhedssektoren og benyttede en markedsdialogproces til at opstille passende miljøkrav.

Leverandører blev opfordret til at kommentere på et udkast til et sæt af kriterier via individuelle dialogmøder. Leverandørerne blev inviteret til disse møder via en online-database for offentlige indkøb.

Som følge af markedsdialogen blev indkøbskravene ændret fra $100 \%$ bomuld til en mere holdbar blanding af polyester og bomuld. Leverandørerne anbefalede, at indkøberne skulle anmode om Oeko-tex 100-mærkede tekstiler, selv om kravene var knap så strenge, da disse i 2014 kunne opfyldes af langt flere leverandører end miljømærker som $\mathrm{fx}$ den nordiske svane eller EU's miljømærke.

Sykehusinnkjøp HF giver følgende råd om markedsdialog i forbindelse med grønne indkøb af tekstiler:

1. Udnyt muligheden for at inkludere kommentarer fra markedet i dine kriterier og hjælp med at sikre, at de er realistiske - uden at være uambitiøse.

2. Overvej at indkalde til individuelle drøftelser for at sikre, at leverandører kan tale frit og ikke hæmmes af, at deres konkurrenter hører på.

3. Husk at lade leverandørerne udfordre dine indkøbsvaner - herunder dit valg af tekstilfiber og forretningsmodel.

Kontakt Evy Pleym på evy.pleym@sykehusinnkjop.no for at få flere informationer. 
Den svenske indkøbsstyrelse (Upphandlingsmyndigheten) hjælper statslige organisationer med at iværksætte en markedsdialog. Hjælpen omfatter møder og en workshop med styrelsen. Se her. Styrelsen er også på vej med et program, der skal udvikle onlineressourcer som hjælp til markedsdialogen.

Online-ressourcebanken omfatter endnu ikke

tekstiler til sundhedssektoren.

Som følge af den hurtige udvikling af nye teknologier/fremgangsmåder inden for produktion af tekstiler er det altid vigtigt at indlede en markedsdialog. Den kan medføre miljøforbedringer, som hospitalsindkøberne ikke er opmærksomme på. Der er mange innovationer i produktionsprocesser og produktdesign i horisonten, som kan give store forbedringer på miljø- og hygiejneområdet (se side 13).

Det skal bemærkes, at man med innovative teknologier af og til risikerer at introducere nye miljøproblemer, og der skal screenes for disse, før man indfører teknologierne.

Indkøbere kan også sikre, at de seneste innovationer anvendes ved at underskrive en udviklingsaftale med leverandørerne: en længerevarende kontrakt med en leverandør, som giver leverandøren mulighed for at benytte nye teknologier i takt med at de kommer frem for yderligere at mindske miljøbelastningen. Udviklingsaftaler kan potentielt opbygges omkring funktionskriterier (se boksen herunder).

\section{ANVENDELSE AF FUNKTIONSKRITERIER I UDBUDSMATERIALE}

For at give mulighed for at udvikle nye produkter med lavere miljøbelastning kan en indkøbskontrakt baseres på funktionelle krav i stedet for at specificere et givet produkt.

Dette bruges primært ved fx indkøb af energi- eller belysningsservices, men det kan også anvendes til tekstiler til sundhedssektoren. En kontrakt kunne fx kræve levering af rene sygeplejerskeuniformer i et tilstrækkeligt antal til at dække et givet antal fuldtidsbeskæftigede medarbejdere, og som opfylder minimumsstandarder for hygiejne, holdbarhed og komfort, men uden at kræve en speciel fibertype. Fibrene kan vælges af den serviceleverandør, der opfylder disse standarder, men med maksimal holdbarhed for at mindske udgifterne og miljøbelastningen.

Den svenske indkøbsstyrelse har udgivet en guide til opstilling af funktionskriterier, som er tilgængelig her. 


\section{EKSEMPLER PÅ LOVENDE INNOVATIONER}

\section{Tørfarvning}

En række innovative virksomheder har udviklet tørfarvningsprocesser. I et eksempel bruges der $\mathrm{CO}_{2}$ i stedet for vand og uden tilsætning af yderligere kemikalier forløber den kemiske proces, der opløser farverne. Desuden kan $\mathrm{CO}_{2}$ genindvindes og genbruges. Med tørfarvning undgår man udledning af spildevand, som kan forårsage store miljøpåvirkninger i produktionsvirksomheder, og man undgår samtidig at skulle tørre tekstilerne mellem processerne, hvilket sparer energi.

\section{Biomimetik}

Biomimetik er anvendelse af naturens designs på menneskefremstillede produkter. Forskning i dette har allerede medført udvikling af tekstiler, som efterligner de smudsafvisende egenskaber, der findes i lotusblade. Andre naturlige behandlinger fokuserer på at efterligne de antimikrobielle egenskaber i krabbe- og hummerskaller. Tekstilanvendelse af disse teknologier vinder allerede indpas og kan medføre tekstiler, som kan vaskes ved lavere temperaturer og samtidig fastholde høje hygiejneniveaver.

\section{Nanomaterialer}

Integrering af nanomaterialer i tekstilsubstrater kan øge tekstilernes holdbarhed og således mindske ressourceforbrug og omkostninger. Nanomaterialer kan gøre fibrene smudsafvisende og krølfri, fjerne statisk elektricitet og elektrisk ledningsevne uden at give køb på komfort og fleksibilitet. 


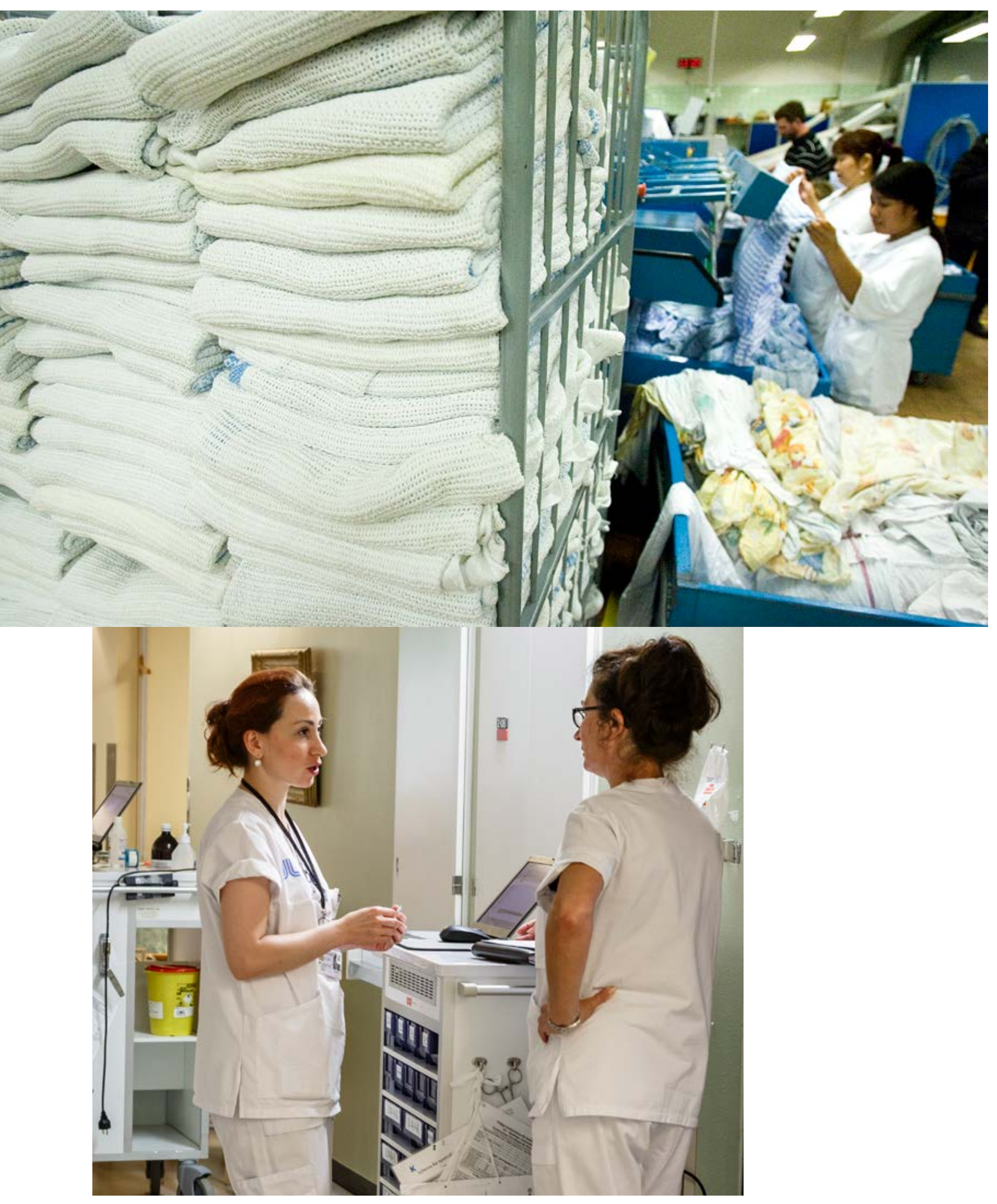




\title{
Links til nyttige dokumenter og ressourcer
}

\author{
Der findes en række vejledende dokumenter, som kan hjæ/pe indkøbere med at \\ overveje bæredygtighed, når de indkøber tekstiler og tekstilservices. Ingen af disse er \\ specifikke for tekstiler til sundhedssektoren.
}

EU: I 2012 udviklede EU valgfri grønne indkøbskriterier for tekstiler med følgende overordnede logik:

- Luftforurening, ozondannelse (smog), bioakkumulering eller ophobning i fødekæden, skadevirkninger på vandlevende organismer eller øget vækst af uønskede vandlevende organismer, som kan forringe vandkvaliteten, og som skyldes anvendelsen af visse pesticider og gødningsstoffer i forbindelse med fremstillingen af fibre samt stoffer, der anvendes til forarbejdning af fibre og færdige tekstilprodukter

- Negative konsekvenser for brugernes arbejdsmiljø som følge af rester af visse sundhedsskadelige stoffer.

- Undgå hurtig opslidning og deraf følgende tekstilaffald ved at fremme brugen af farveægte stoffer, som ikke kryber i vask
- Køb økologisk fremstillede tekstiler

- Køb brugte tekstiler, som kan genbruges til deres oprindelige formål, eller køb tekstiler, som indeholder genanvendte fibre

- Køb tekstiler, hvor der er anvendt en begrænset mængde miljøskadelige stoffer i produktionen

- Køb tekstiler med lavere restkoncentrationer af sundhedsskadelige stoffer

- Køb tekstiler, der opfylder mindstekravene til farveægthed og dimensionsstabilitet
Kriterierne omfatter de centrale kriterier (minimumskriterier) og de udvidede kriterier (mere ambitiøse) for

- rester af pesticider i naturlige fiberprodukter

- rester af kemikalier og stoffer, der potentielt anvendes i fremstillingsprocesserne

- begrænsninger af brugen af særlige farvestoffer

- egenskaber vedrørende holdbarhed som fx form og farveægthed

Kriterierne indeholder også forslag til tildeling af point for økologisk produktion ved at levere naturlige fibre og bruge genanvendte fibre i et produkt.

I GPP-kriterierne gælder de fleste begrænsninger af miljøfarlige kemikalier tilstedeværelsen af rester i slutproduktet og ikke anvendelsen under produktionen. Undtagelsen er nogle farvestoffer, som GPP-kriterierne specifikt forbyder at anvende i produktionen.
Ikke desto mindre vil begrænsninger i restprodukter af miljøfarlige kemikalier i slutproduktet sandsynligvis også medføre en begrænset anvendelse i produktionen. Desuden vil tildeling af point for anvendelse af produkter med økologisk dyrket bomuld og andre økologiske naturlige fibre reducere brugen af pesticider.

GPP-kriterierne er generelt mindre strenge end de almindeligt brugte miljømærker som det nordiske svanemærke og EU's miljømærke (se afsnit 4, side 22). GPP-kriterierne er i øjeblikket under revision og et revideret sæt forventes i starten af 2017.

Nationalt: De statslige indkøbsstyrelser i nogle af de nordiske lande bruger EU-kriterierne som en direkte vejledning for tekstilindkøbere: fx Danmark, Norge, Finland. 


\section{NATIONALE STANDARDER FOR HYGIEJNE I SUNDHEDSSEKTORENS VASKERIER}

Når man indfører grønne indkøbskriterier for vaskeriservice, skal indkøberne også respektere landets retningslinjer for minimumshygiejnestandarder for disse serviceydelser.

EU-standarden EN 14065 beskriver en fremgangsmåde for risikostyring med henblik på konstant at sikre den mikrobiologiske kvalitet af vaskeribehandlede tekstiler, og denne standard er overført til tilsvarende nationale standarder. Standarden EN 14065 er for nylig blevet opdateret. Links til EU-standarden og de tilsvarende nationale standarder kan findes ved at klikke her: EU-standarder; Dansk version; Svensk version; Finsk version; Norsk version.

EN 14065 omhandler grænseværdier og kontrol- og overvågningssystemer for biokontamination i vaskericyklussens forskellige stadier, men definerer ikke vaskemetoder, der undgår biokontamination. Dog har mindst tre nordiske lande standarder eller retningslinjer, som definerer vaskeri- og vaskeriservicemetoder, der skal følges for at undgå biokontamination.

- Dansk standard om håndtering af genanvendelige tekstiler i sundhedssektoren

- Svensk håndbog om tekstiler i sundhedssektoren

- Norsk standard om infektionskontrol af vaskeribehandlede sundhedstekstiler 
Disse varierer med hensyn til kravene til vasketemperaturer ved varmedesinfektion: Den norske standard kræver $85^{\circ} \mathrm{C}$ i 10 minutter, den danske standard min. $80^{\circ} \mathrm{C} \mathrm{i}$ 10 minutter, og den svenske håndbog anbefaler min. $70^{\circ} \mathrm{C}$ i 10 minutter.

Både den norske og danske standard giver mulighed for lavere vasketemperaturer, under forudsætning af at der bruges vaskemidler med samme steriliserende virkning. De tilsvarende behov skal overvåges løbende. Ifølge en førende virksomhed inden for vaskeriservice findes der miljømærkede vaskemidler, som kan opfylde disse alternative krav. Dette kan give nettofordele på miljøområdet sammenlignet med at sterilisere under høje temperaturer.

Den svenske håndbog er en vejledning snarere end en standard. En videnskabelig undersøgelse på Uppsala Hospital konstaterede, at sænkning af temperaturerne til $60^{\circ} \mathrm{C}$ ikke øgede risiciene for biokontamination, under forudsætning af at vasken blev efterfulgt at tørretumbling ved en temperatur på over $110^{\circ} \mathrm{C}$. Til trods for dette reduceres energiforbruget gennem den fulde vaskericyklus (Tano og Melhus, 2014)*.

*Tano, E, og Melhus, A. (2014) Level of decontamination after washing textiles at $60^{\circ} \mathrm{C}$ or $70^{\circ} \mathrm{C}$ followed by tumble drying. Infect Ecol Epidemiol. 2014 Nov 11;4:24314. 


\section{CSR OG TEKSTILINDKøB}

Corporate Social Responsibility (CSR) eller virksomhedernes sociale ansvar henviser til forretningspraksis, der involverer initiativer til gavn for samfundet. Udover den miljømæssige indsats, der behandles i denne vejledning, indgår etiske arbejdsmetoder, antikorruption og menneskerettigheder. Disse aspekter er relevante, når der indkøbes tekstiler til sundhedssektoren, og i nogle nordiske lande har de været i fokus i mange år.

I Sverige har alle regioner $\mathrm{fx}$ et fælles adfærdskodeks, som leverandører skal underskrive og besvare spørgsmål vedrørende opfyldelse. Adfærdskodekset er baseret på FN's menneskerettighedserklæring, ILO's otte kernekonventioner, FN's konvention om barnets rettigheder, FN's konvention mod korruption og den relevante arbejds- og miljølovgivning i produktionslandet. Adfærdskodekset kan findes her.

De svenske regioner har også en fælles webportal med vejledninger og information om CSR, hvor tekstiler betragtes som et af ni risikoområder inden for indkøb til sundhedssektoren. Udvalgte regioner er ansvarlige for overholdelse og audits i hver specifik produktgruppe, og fx har man i de seneste år auditeret tekstilproduktionen i Indien og Pakistan. Risikovurderingen kan findes her.

De danske myndigheder, der er ansvarlig for indkøb, inkluderer yderligere etiske og miljømæssige principper, der delvis omfatter Global Compact-principperne.

Den norske styrelse vejleder også om etiske betragtninger. Heri fremhæves de initiativer, der har til hensigt at takle de dårlige arbejdsvilkår i tekstilproduktionen. Better Cotton Initiative, Clean Clothes Campaign, ACCORD og IPEC. Blandt disse er Better Cotton Initiative og ACCORD de mest anvendelige for indkøberne, da man kan se, hvilke mærker/producenter der er omfattet af initiativerne. Der er dog ingen garanti for, at tøj, der er fremstillet til disse medlemmer (endnu) lever op til initiativernes principper og målsætninger.

EU's miljømærke, det nordiske svanemærke og Bra Miljöval indeholder kriterier, der vedrører arbejdsrettigheder på produktionsstedet for tekstilerne (se afsnit 4, side 22). Andre nyttige links:

- World Wide Responsible Apparel

- CSR compass 
Den svenske styrelse for offentlige indkøb har en hjemmeside, der både indeholder retningslinjer og et omfattende baggrundsdokument, som beskriver miljøpåvirkningerne som følge af forbruget af tekstiler, lovgivningen vedrørende brug af kemikalier i tekstilproduktionen og til sidst angiver en liste over miljøfarlige kemikalier og stoffer, som bør begrænses gennem udbudskriterierne. Listen over kemikalier er væsentlig mere omfattende end EU's ikke-bindende GPP-kriterier og nærmer sig de kemisk relaterede kriterier i EU's miljømærke og det nordiske svanemærke for tekstiler.

Endelig leverer den svenske styrelse for offentlige indkøb, i modsætning til styrelserne i de øvrige lande, også et baggrundsdokument og en vejledning for indkøb af vaskeriservice. Disse dokumenter dækker en række emner vedrørende brug og håndtering af kemikalier og vaskemidler i vaskeprocesserne, energi- og vandforbrug og udledninger til luft fra vaskeriservices.
De af EU og på nationalt niveau foreslåede GPPkriterier kan alle opfyldes fuldt tilstrækkeligt med tekstiler, der er certificeret under det nordiske svanemærke, EU's miljømærke og Bra Miljöval. De svenske kriterier for vaskeriservice kan tilsvarende opfyldes af tekstilservices, der er certificeret med det nordiske svanemærke (se afsnit 4, side 22-24).

Selv om det ikke er et fokusområde for denne guide giver boksen på side 18 også hjælp til at inkludere etiske kriterier $\mathrm{i}$ indkøbsprocesserne.

I sidste ende skal indkøberne vælge kriterier, der svarer til deres behov og miljømæssige (og etiske) ambitioner. Side 20-21 angiver et udvalg af grundlæggende kriterier, der anvendes af Sykehusinnkjøp $H F$, den centrale indkøber i Norge, i en nylig udbudsproces for uniformer. Udbuddet omfatter også yderligere kriterier relateret til affaldshåndtering af tekstiler, der indeholder miljøfarlige kemikalier, og kriterier for produkternes emballering. Kriterierne er mindre omfattende end EU's GPP-kriterier.

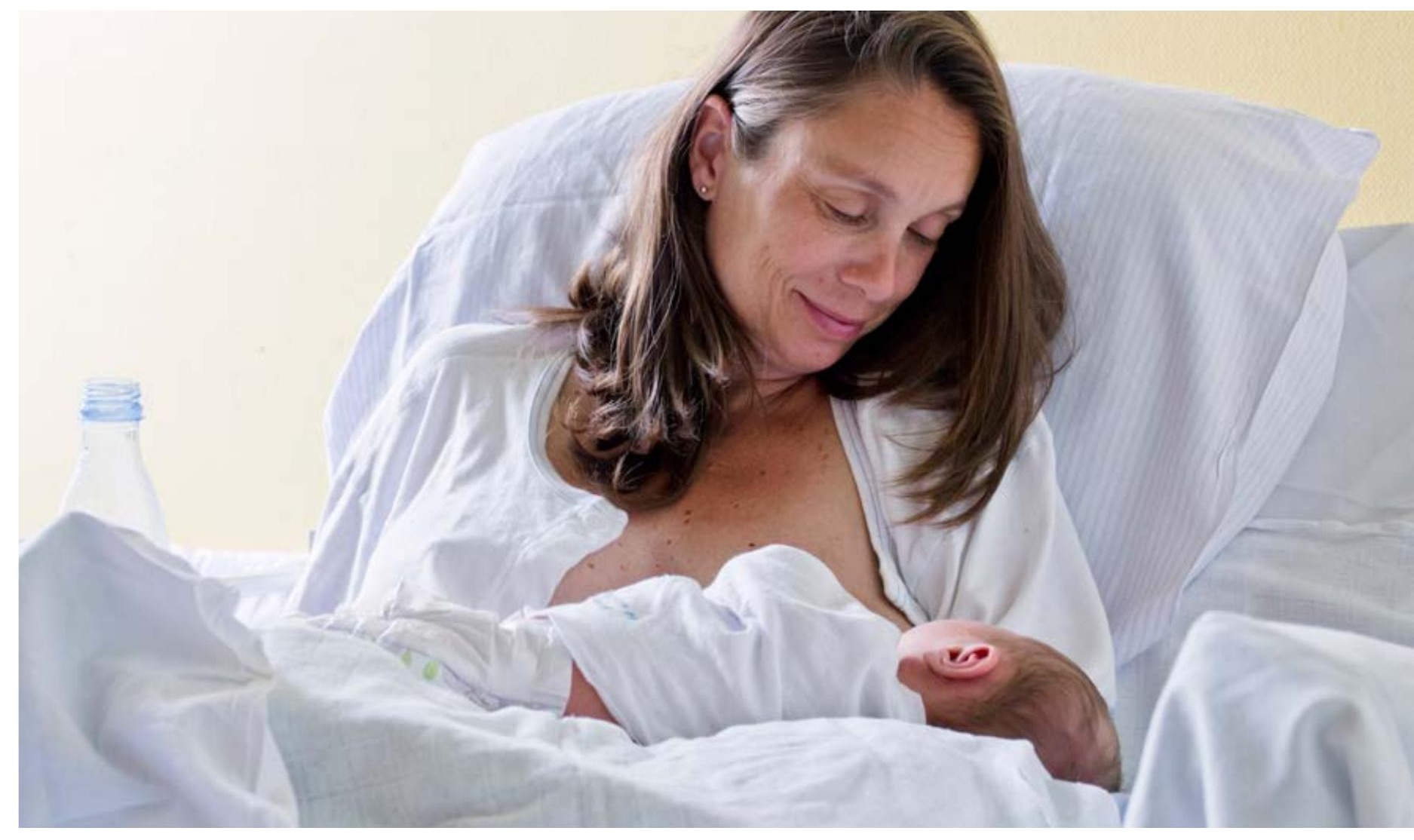




\section{Eksempel på kriterier anvendt i et udbud for personaleuniformer}

\section{MINIMUMSKRITERIER FOR KEMIKALIER}

\section{Overholdelse af lovkrav}

De tilbudte produkter skal overholde de krav, der er angivet i forskrifterne for begrænsning af brug af miljøfarlige kemikalier og andre produkter (Produktforskrifter FOR-2004-06-01922). De tilbudte produkter skal være i overensstemmelse med kravene i kemikalielovgivningen REACH.

\section{Generelle krav:}

Produkterne må ikke indeholde stoffer på EU's kandidatliste eller den norske prioriteringsliste. Dette gælder også for brug af hjælpe kemikalier og vaskemidler

\section{Brug af pesticider}

For produkter, der er fremstillet af bomuld eller andre naturlige cellulosefibre, må slutproduktet højst indeholde 0,05 ppm af hvert af følgende stoffer, og det samlede indhold må ikke overstige 0,75 ppm:

\section{- 2,4,5-T, aldrin, captafol, chlordan,} chlordimeform, DDT, dieldrin, dinoseb og salte, endrin, heptachlor, hexachlorbensen, hexachlorsyclohexan, $\alpha$, hexachlorsyclohexan, $\beta$, hexachlorsyclohexan, $\delta$, metamidophos, monocrotophos, parathion, parathion-methyl, propethamphos, toxaphen

\section{Brandhæmmere}

Der må ikke være kemiske brandhæmmere i de indkøbte stoffer, medmindre dette er absolut nødvendigt på grund af tekstilernes funktion. Hvis der kræves brandhæmmer, vil det fremgå af udbudsmaterialet. I sådanne tilfælde skal der anvendes fosfat-og/ eller kvælstofbaserede organiske stoffer eller brandhæmmere med tilsvarende eller bedre sundheds-og miljømæssige karakteristika for flammebestandige tekstiler. Halogenerede brandhæmmere må under ingen omstændigheder anvendes.

\section{Alkyl-fenol-etoxylater}

Der må ikke være alkyl-fenol-etoxylater i produktet. (Nonylfenol er begrænset ifølge REACH Bilag XVII og prioriteringslisten, men kan alligevel forekomme i produkter). 


\section{MINIMUMSKRITERIER FOR KVALITET}

\section{Dimensionsændringer under vask og tørring}

Dimensionsændringer efter vask og tørring må ikke overstige:

+/- 3\% for vævede produkter af bomuld eller bomuldsblanding.

+/- $2 \%$ for ikke-vævede produkter af blandede uldprodukter og syntetiske fibre.

+ - $4 \%$ for strikvarer.

$+/-6 \%$ for grove strikvarer (kraftig strik).

$+/-5 \%$ for strikvarer (interlock).

+/- 7\% frottéhåndklæder og fine ribstrikkede produkter.

Kravet gælder ikke for fibre eller garner, produkter der tydeligt er mærket "kun kemisk rens" eller tilsvarende. Der skal udføres prøvninger i henhold til EN ISO 6330, ISO 5077 eller tilsvarende. Følgende procedure skal overholdes ved prøvning: Vask tre gange ved den temperatur, der er angivet på produktet, med efterfølgende tørring $i$ tørretumbler, medmindre anden tørreproces er angivet på produktet.

\section{Farveægthed ved vask (vaskeægthed)}

Vaskeægtheden skal være mindst note 3-4 for farveændring og mindst note 3-4 for farveafsmitning. Kravene gælder ikke for produkter, der tydeligt er mærket "kun kemisk rens" eller tilsvarende, hvide produkter eller produkter, der hverken indeholder farver eller print. Der skal udføres prøvninger i henhold til EN ISO 105-CO6 eller tilsvarende. Dette betyder en enkelt vask ved den temperatur, der er angivet på produktet.

\section{Våd gnideægthed}

Den våde gnideægthed skal være mindst note 2 -3. Kravet gælder ikke for hvide produkter eller produkter, der hverken indeholder farver eller print. Der skal udføres prøvninger i henhold til EN ISO $105 \times 12$ eller tilsvarende.

\section{Tør gnideægthed}

Farveægtheden ved tør gnidning skal være mindst note 4 . Kravet gælder ikke for hvide produkter eller produkter, der hverken indeholder farver eller print. Der skal udføres prøvninger i henhold til EN ISO 105 X12 eller tilsvarende.

\section{TILDELINGSKRITERIER}

\section{$\varnothing$ kologisk dyrket bomuld eller andre naturlige fibre}

Der tildeles yderligere point i forhold til andelen i vægt af økologisk dyrket bomuld eller andre naturlige fiberprodukter, som dyrkes økologisk. For at blive betragtet som økologiske skal fibrene være dyrket i overensstemmelse med bestemmelserne i forordning (EF) $\mathrm{nr}$. 834/2007 vedrørende økologisk produktion og mærkning af økologiske produkter og tilbagekaldt forordning (EØF) nr. 2092/91. 
Afsnit 4

\section{Et hurtigt overblik over miljømærker}

Beslutningen om at medtage et miljømærke i et udbud skal overvejes nøje og kræver viden om, hvad hvert miljømærke vedrører. Du skal vælge et miljømærke, der matcher dine miljømæssige ambitioner, men pas på ikke at begrænse puljen af potentielle leverandører for meget. Det kan også være, at ingen af miljømærkerne behandler alle relevante miljøhensyn, og at du måske ønsker at inkludere yderligere kriterier.

Siden 2014 har det i EU været lovligt at angive miljømærker direkte i et udbud som et kriterie, men kun miljømærker, der opfylder visse mærkekrav (se afsnit 3.5.1 i håndbogen Buying Green!). Denne nye regel gør det nemmere for indkøbere at opstille miljøkriterier og for leverandører at kontrollere, om de opfylder dem. I Danmark skal indkøbere dog give plads til leverandører, hvis produkter kunne opfylde kriterierne, uden at de rent faktisk har fået tildelt et miljømærke. Leverandører skal fremlægge dokumentation for dette, som kan læses på en time! Dette lægger nogle yderligere byrder på indkøberen.

Der er mange mærker for tekstilprodukter, men kun det nordiske svanemærke har kriterier for tekstilservices. Relevante miljømærker for tekstiler til sundhedssektoren omfatter det nordiske svane-

mærke, EU's miljømærke (der også kaldes EUblomsten), GOTS (Global Organic Textile Standard) og det svenske Bra Miljöval (Godt miljøvalg). Selv om det strengt taget ikke er et miljømærke angives mærket Oeko-Tex 100 også af og til i grønne indkøbskriterier. BlueSign-mærket anvendes stadig kun til udendørsprodukter og er derfor endnu ikke relevant for hospitalsindkøbere, med udendørs arbejdsbeklædning som en mulig undtagelse.

Vær opmærksom på, at ikke alle miljømærker overholder de kriterier, der er opstillet af EU-Kommissionen i håndbogen Buying Green!, og som tillader, at de kan anvendes $\mathrm{i}$ indkøbsudbud.
Skemaet herunder giver en hurtig sammenligning af de miljøproblemer, der omfattes af de mest relevante mærker. To flueben angiver et mere detaljeret og/eller omfattende kriterie end et enkelt flueben.

En sammenligning af de samme mærker med hensyn til særlige begrænsninger af kemikalier og stoffer er også foretaget af den svenske styrelse for offentlige indkøb og kan findes her.

Formålet med Oeko-Tex-mærket er at beskytte tekstilbrugere mod miljøfarlige kemiske reststoffer $\mathrm{i}$ beklædning og tekstiler, der sættes til salg. Begrænsninger af kemikalier under andre miljømærker gælder for hele livscyklussen og har til hensigt at reducere påvirkningerne af økosystemer og mennesker i hele værdikæden, herunder slutbrugeren. Oeko-Tex har lanceret et mærke (STeP), som dækker miljøaspekter af produktionen, men det er mere et mærke for miljøstyring af produktionssteder, end det er et produktmærke. Det har derfor kun begrænset relevans for indkøberne.

Det nordiske svanemærke har et mærke og et kriterie for tekstilservices. Mærket omfatter særlige kriterier for vask af hospitalstekstiler for at tage hensyn til hygiejnestandarder. Kriterierne omfatter energiforbrug, vandforbrug og vaskemidler/kemikalier på vaskerier og anvendelse af emballage og transport af tekstilerne. Mærket omfatter også krav til en minimumsprocent af miljømærkede tekstiler i de produkter, der leases ud af tekstilservicevirksomheden. 


\section{Hurtig sammenligning af mærker til tekstilprodukter}

\begin{tabular}{|c|c|c|c|c|c|}
\hline & $\begin{array}{l}\text { Nordisk } \\
\text { svane }\end{array}$ & $\begin{array}{l}\text { EU's mil- } \\
\text { jømærke }\end{array}$ & Bra Miljöval & $\begin{array}{l}\text { GOTS (kun } \\
\text { naturlige fibre) }\end{array}$ & $\begin{array}{l}\text { Oeko-tex } \\
100\end{array}$ \\
\hline $\begin{array}{l}\text { Økologisk andel } \\
\text { (naturlige fibre) }\end{array}$ & $\checkmark$ & $\checkmark$ & $\checkmark \checkmark$ & $\checkmark \checkmark$ & \\
\hline Genanvendt indhold & $\checkmark$ & $\checkmark$ & $\checkmark$ & & \\
\hline $\begin{array}{l}\text { Kemiske begrænsninger i } \\
\text { produktionsprocesser }\end{array}$ & $\checkmark \checkmark$ & $\checkmark \checkmark$ & $\checkmark \checkmark$ & $\checkmark \checkmark$ & \\
\hline $\begin{array}{l}\text { Begrænsninger af rest- } \\
\text { kemikalier i produktet }\end{array}$ & $\checkmark \checkmark$ & $\checkmark \checkmark$ & & $\checkmark \checkmark$ & $\checkmark \checkmark$ \\
\hline Styring af spildevand & $\checkmark \checkmark$ & $\checkmark \checkmark$ & $\checkmark \checkmark$ & $\checkmark \checkmark$ & \\
\hline Reduceret luftforurening & & $\checkmark$ & $\checkmark \checkmark$ & & \\
\hline $\begin{array}{l}\text { Reduceret mængde } \\
\text { af affald }\end{array}$ & & & $\checkmark$ & $\checkmark$ & \\
\hline $\begin{array}{l}\text { Produktkvalitet og } \\
\text { holdbarhed }\end{array}$ & $\checkmark$ & $\checkmark$ & & $\checkmark$ & \\
\hline Emballagematerialer & $\checkmark$ & & $\checkmark \checkmark$ & $\checkmark \checkmark$ & \\
\hline $\begin{array}{l}\text { Arbejdsrettigheder/ } \\
\text { arbejdsmiljø }\end{array}$ & $\checkmark \checkmark$ & $\checkmark \checkmark$ & $\checkmark \checkmark$ & & \\
\hline $\begin{array}{l}\text { Certificering } \checkmark \checkmark \\
\text { 3. part } \checkmark 2 \text {. part }\end{array}$ & $\checkmark \checkmark$ & $\checkmark \checkmark$ & $\checkmark \checkmark$ & $\checkmark \checkmark$ & $\checkmark \checkmark$ \\
\hline
\end{tabular}

Kilde: Sammenligning foretaget af Planmiljø

Som indkøber kan der være yderligere kriterier, du gerne vil lægge til grund. Disse kan også inspireres af de kriterier, der findes i miljømærker. For eksempel kan en tekstilserviceleverandør modtage en nordisk svanecertificering, hvis denne opfylder minimumskriterierne og yderligere opnår 15 point ud af 65 mulige tildelingspoint i de valgfri kriterier. En mere ambitiøs indkøber kan vælge at sætte en højere grænse på måske 25 point i forhold til de valgfrie kriterier, som serviceleverandørerne skal opfylde.

Endelig skal man, før man bruger miljømærker i et udbud for et specifikt produkt, sikre sig, at der er mindst to eller tre leverandører, som kan opfylde dette krav. I modsat fald kan du ende med at betale en ikke- konkurrencedygtig pris. De fleste miljømærker har en liste over produkter, der er blevet certificeret inden for forskellige kategorier. Det vil også hjælpe at indlede en markedsdialog (se afsnit 2, side 10-12).

Kriterierne for de forskellige miljømærker kan findes her:

- Nordisk svanemærke for tekstiler

- Nordisk svanemærke for tekstilservices

- EU's miljømærke for tekstiler

- Bra Miljöval

- GOTS

- Oeko-tex 100 


\section{Valg af fiber}

At vælge den rigtige fiber kan give betydelige miljøfordele på alle mulige måder. For eksempel kan valg af fiber påvirke vaskeriets energiforbrug, produktets holdbarhed og produktionens miljøpåvirkninger. Det er også vigtigt for komfort og hygiejne.

Når du vælger fiber til dine tekstiler, er det vigtigt at vurdere egenskaberne og den miljøbelastning, der følger med. For eksempel:

\section{- Forskellige fibre har forskellige miljøprofiler} under produktionen: Diagrammet nedenfor er udviklet ved hjælp af livscyklusanalysemetoder (LCA). Bomuld og polyester har tendens til at have større miljøpåvirkninger i produktionen end nogle af de nye fibre. Diagrammet indeholder ikke toksicitetsvirkninger, som ville placere bomuld $i$ et noget dårligere lys som følge af kraftig brug af pesticider i konventionel bomuldsdyrkning. Disse kan reduceres ved at bruge økologisk dyrket bomuld.

- Nogle fibre er mere holdbare end andre: Polyester eller en blanding af polyester og bomuld kan overleve flere vaskecyklusser end $100 \%$ bomuld 3 . Tilføjelse af en easy care finish, kan også øge levetiderne.

- Syntetiske fibre er nemmere at vaske: Da de absorberer mindre vand, bruger de mindre energi under tørretumblingen. Nye undersøgelser viser også, at de kan vaskes ved lavere temperaturer end bomuld uden at forringe hygiejnen, selv om dette ikke anerkendes i gældende nationale hygiejnestandarder.

- Rene fibre og syntetiske materialer er lettere at genanvende efter brug: $100 \%$ polyester kan $\mathrm{i}$ teorien genanvendes i nye tekstiler igen og igen og igen. $100 \%$ bomuld kan også genanvendes i nye tekstiler, men det skal blandes med $80 \%$ jomfruelig bomuld for at bevare tekstilkvaliteten. Det er vanskeligere at genanvende fiberblandinger som fx polyester/bomuld. Meget vigtigt: I alle strategier for genanvendelse af hospitalstekstiler er det vigtigt at være opmærksom på ikke at forringe holdbarheden. En længere levetid giver langt større miljøfordele end genanvendelse.

- Syntetiske fibre kan føre til havforurening med mikroplast, selv om dette er en meget mindre forureningskilde end fx bildæk. Det forventes, at dette problem kan løses i fremtiden ved udvikling af specielle spildevandsfiltre til vaskerier ${ }^{4}$. 
Sammenligning af livscykluspåvirkninger fra forskellige fibre

\begin{tabular}{|c|c|c|c|c|c|}
\hline & Energy use & Water use & $\begin{array}{l}\text { Greenhouse } \\
\text { gasses }\end{array}$ & Waste water & $\begin{array}{l}\text { Direct land } \\
\text { use }\end{array}$ \\
\hline $\begin{array}{l}\text { Decreasing } \\
\text { environment al } \\
\text { impact }\end{array}$ & $\begin{array}{l}\text { Acrylic } \\
\text { Nylon } \\
\text { Polyester/ } \\
\text { PTT } \\
\text { Regen. } \\
\text { cellulosic } \\
\text { (viscose, } \\
\text { Modal) } \\
\text { PLA/ } \\
\text { Cotton/ } \\
\text { Lyocell } \\
\text { Wool } \\
\text { Natural } \\
\text { bast fibres } \\
\text { (nettle, } \\
\text { hemp, flax) }\end{array}$ & $\begin{array}{l}\text { Cotton } \\
\text { Silk } \\
\text { Nylon } \\
\text { Regen. } \\
\text { cellulosic } \\
\text { Acryl } \\
\text { Hemp } \\
\text { Wool } \\
\text { Natural bast } \\
\text { fibres } \\
\text { Polyester }\end{array}$ & $\begin{array}{l}\text { Nylon } \\
\text { Polyester } \\
\text { Lyocell } \\
\text { PLA } \\
\text { Viscose } \\
\text { Modal } \\
\text { Cotton } \\
\text { Natural bast } \\
\text { fibres } \\
\text { Wool }\end{array}$ & $\begin{array}{l}\text { Wool } \\
\text { Regen. } \\
\text { cellulosic } \\
\text { Natural bast } \\
\text { fibres } \\
\text { Nylon } \\
\text { Polyester }\end{array}$ & $\begin{array}{l}\text { Wool } \\
\text { Ramie } \\
\text { Cotton } \\
\text { Flax } \\
\text { Hemp } \\
\text { Viscose } \\
\text { and Modal } \\
\text { Jute } \\
\text { PLA } \\
\text { Lyocell }\end{array}$ \\
\hline
\end{tabular}

Kilde: EU Technical Background Report to GPP criteria for textiles 2011

Den anvendte fiber skal også opfylde andre krav, ikke mindst hygiejnestandarder ( $f x$ infektionskontrol af tekstiler til operationsstuer, se afsnit 6, side 28-29) og krav om brugerkomfort.

\section{Komfort: Er bomuld virkelig bedst?}

På trods af de miljømæssige ulemper kan bomuld være den foretrukne fiber med hensyn til komfort for hospitalets ansatte og patienter. Dette kan dog hidrøre fra forudfattede opfattelser snarere end faktisk erfaring.

Der findes laboratorietests af komfort, der bruger standard prøvningsteknikker til at måle:
- Varmemodstand

- Modstand over for vanddamp

- Luftgennemtrængning

- Overfladefriktion og ruhed (Kawabata Evaluation System)

- Fugthåndtering (AATCC standard)

- Trækstyrke

Men for at nedbryde fordomme kan det være en god idé at brugerteste de tilgængelige tekstilmuligheder på personale og patienter, før der træffes et endeligt valg. Brugertests kan vise, at alternative fibre giver en fuldt acceptabel komfort for personalet, samtidig med at der opnås miljømæssige og økonomiske fordele. Se et eksempel på et pilotprojekt, som gav præcis dette resultat, i boksen på side 26 .

${ }^{5}$ http://www.greenercleaner.net/natural-or-synthetic-textiles/ 


\section{INNOVATIVT INDKØB AF UNIFORMER PÅ RAWICZ HOSPITAL}

I 2011 gik Rawicz County Hospital i Polen ind i LCB-Healthcare Network, et EU-støttet netværk for innovative indkøb. Et pilotprojekt for innovative indkøb blev igangsat på hospitalet med fokus på bæredygtige indkøb af personaleuniformer.

Pilotprojektet startede med, at man spurgte sygeplejersker, læger og andre ansatte om de primære funktionelle parametre, de krævede for deres uniformer. Dette gav personalet indflydelse, og resultatet var følgende prioriteter: De nye uniformer skulle være funktionelle, pæne, brugervenlige, nemme at rengøre, holdbare og billige.

Ved at specificere disse funktionelle krav i udbudsdokumenterne i stedet for at specificere materiale, fibertype, design osv. fik indkøbere og leverandører mulighed for at undersøge mere innovative løsninger. Efter at resultaterne af pilotprojektet havde vakt interesse hos yderligere otte hospitaler i Polen, var det desuden muligt at tiltrække et bredt udvalg af leverandører til at afgive tilbud.

Hospitalet kommunikerede proaktivt sine behov og markedskrav, og et åbent møde blev afholdt med potentielle leverandører. Feedbacken var meget positiv, og den åbne specifikation gav leverandører mulighed for at differentiere deres produkter på andre faktorer end indkøbspris. Ikke mindst fik totalomkostningerne (TCO - se afsnit 7, side 3031) forrang for anskaffelsesudgiften ved vurderingen af tilbuddene fra leverandørerne.

Resultatet af markedsdialogen og udbudsprocessen var uniformer produceret af en blanding af polyester og tencel (et produkt baseret på eukalyptus). Materialeblandingen viste sig at være lige så hårdfør over for vaskeprocesserne, hurtigere tørrende, mindre modtagelig over for snavs, og den blev generelt godkendt for sin kvalitet og funktionalitet. Skønt anskaffelsesprisen var højere end i visse af konkurrenternes tilbud, var totalomkostningerne de laveste, hvilket skyldtes reducerede vaskeriomkostninger og længere levetid.

Kontakt Marcin Kautsch på e-mail: mxkautsc@wp.pl, hvis du ønsker yderligere information. 


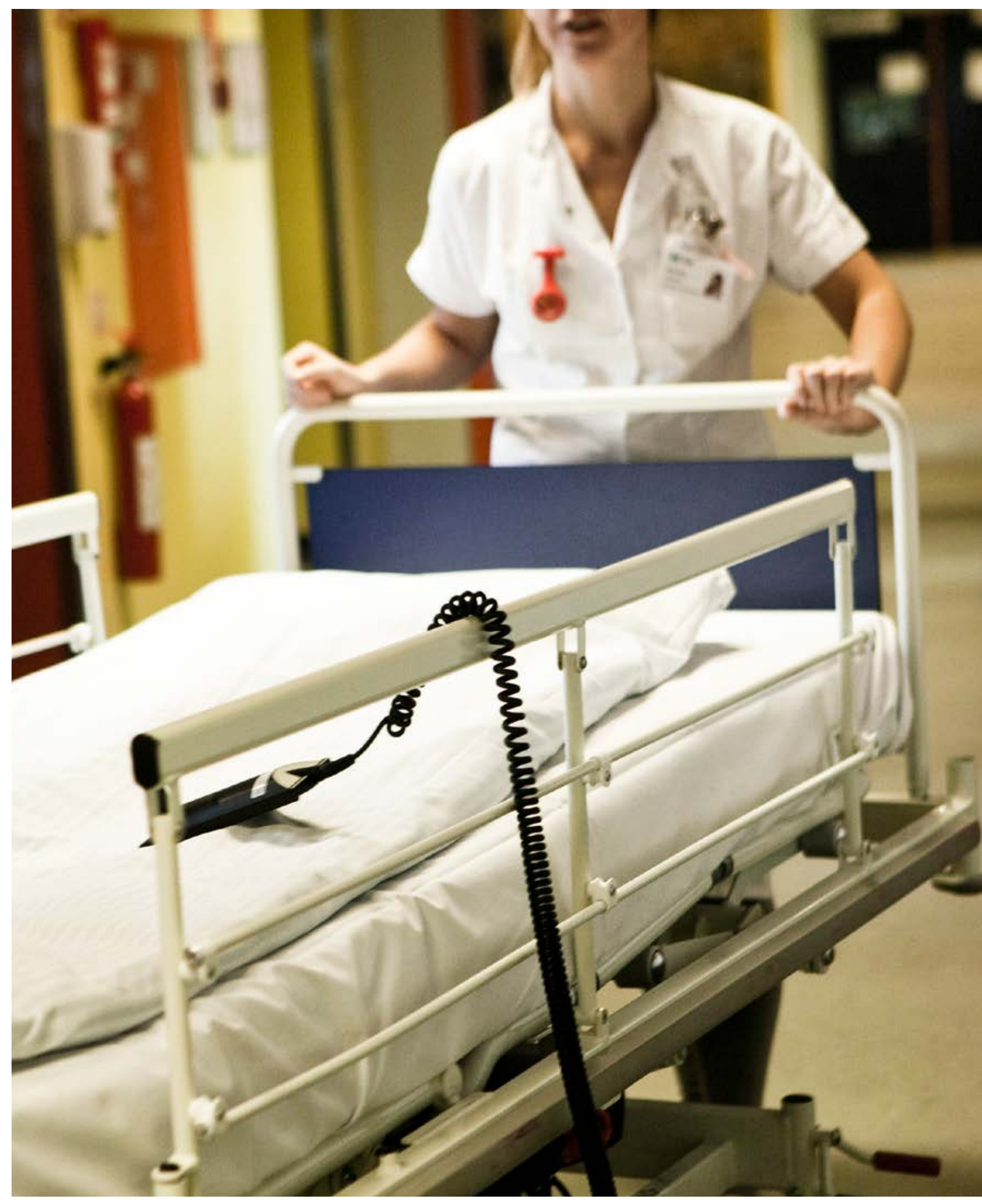


Afsnit 6

\section{Engangs- kontra flergangstekstiler}

Der er både fordele og ulemper ved nonwoven til engangsbrug og flergangs

tekstilprodukter. Dette gælder især for tekstiler til operationsstuer, hvor

infektionskontrol er af altafgørende betydning. Udover hygiejnen er andre vigtige

variabler de samlede udgifter pr. anvendelse, funktionalitet og komfort og, hvilket er

særligt relevant her, miljøhensyn.

Engangsbrug og moderne genbrugelige tekstiler til operationsstuer er mere eller mindre på samme niveau med hensyn til barrierebeskyttelse, som er et kritisk element i infektionskontrollen. Dette kræver, at flergangstekstiler vaskes og steriliseres ifølge godkendte procedurer efter hver brug.

Minimering af udslip af luftbårne partikler er også vigtigt for infektionskontrollen. Moderne genanvendelige barrieretekstiler produceret af gennemgående fibre har et meget lavere potentiale for at fnugge end traditionelle bomuldsstoffer og præsterer ligeså godt som nonwoven-produkter til engangsbrug. De giver også god komfort og åndbarhed.

Undersøgelsesresultaterne er blandede med hensyn til omkostning pr. anvendelse af engangsprodukter kontra flergangsprodukter, og sammenligningen vil være meget lande specifik. Højere lønomkostninger kan tale for engangsprodukter, mens høje udgifter til bortskaffelse taler for flergangsprodukter.
På den anden side har flere undersøgelser vist, at flergangstekstiler giver betydelige miljøfordele sammenlignet med engangstekstiler ${ }^{6,7,8,9}$. En gennemgang af seks livscyklusanalyser viste, at engangstekstiler har 2-3 gange højere CO2-udslip og energi- og vandforbrug pr. anvendelse på operationsgangen end moderne genbrugsprodukter ${ }^{10}$. Eftersom moderne flergangstekstiler er bedre eller sammenlignelige med engangstekstiler i andre henseender, forekommer de at være et mere bæredygtigt valg.

\section{Sammenligning af flergangs og engangstekstiler til operationsstuer}

Brug af flergangstekstiler til operationsstuer afhænger af, om hospitalet har kapacitet til at sterilisere flergangsoperationspakker.

Følgende råd kan gives til hospitaler og deres vaskeriservice, som ønsker at skifte fra engangsprodukter til flergangstekstiler til operationsstuer ${ }^{11}$ :

\footnotetext{
${ }^{6}$ Overcash (2012) A Comparison of Reusable and Disposable Perioperative Textiles: Sustainability State-of-the-Art 2012 http://www.ncbi.nlm.nih.gov/pubmed/22492184

${ }^{7}$ Carre (2008) LCA Comparing Laundered Surgical Gowns with Polypropylene Based Disposable Gowns http://trlaa.com.au/wordpress/wp-content/uploads/Lifecycle_Assessment_Study.pdf

${ }^{8}$ Mikusinska (2012) Comparative Life Cycle Assessment of Surgical Scrub Suits

http://kth.diva-portal.org/smash/get/diva2:574013/FULLTEXT01.pdf

${ }^{9}$ Eriksson och Berg (2003) Livscykelanalys av Operationsrockar

http://www.vgregion.se/upload/Tv\%C3\%A4tteriet\%20Alings\%C3\%A5s/LCA\%2Ooperationsrockar_granskad.pdf

${ }^{10}$ Overcash (2012) A Comparison of Reusable and Disposable Perioperative Textiles: Sustainability State-of-the-Art 2012 http://www.ncbi.nlm.nih.gov/pubmed/22492184

${ }^{11}$ https://americanlaundrynews.com/articles/winning-sale-reusable-surgical-textiles-part-1
} 


\begin{tabular}{|l|c|c|c|}
\hline & Cotton reusable & Disposables & High tech reusable \\
\hline Barrier effect & - & + & + \\
\hline Cleanliness & + & $?$ & + \\
\hline Particle emission & - & - & + \\
\hline $\begin{array}{l}\text { Comfort and } \\
\text { breathability }\end{array}$ & + & - & + \\
\hline Environmental impact & $+/-$ & + & + \\
\hline Functionality & - & $+/-$ & $+/-$ \\
\hline Cost effective & $+/-$ & $+/-$ & + \\
\hline Value for money & - & & + \\
\hline
\end{tabular}

Kilde: Petel, M. (2014) $)^{12}$

1. Start i det små. Begynd med en plan, der kan håndteres, fx håndklæder og personalebeklædning.

2. Samarbejd med din leverandør af flergangsprodukter til operationsstuer. Udnyt din leverandørs viden og ressourcer. Kontakt andre vaskerier, som med succes har forvandlet hospitalernes programmer for operationsstuer til flergangsprodukter.

3. Udarbejd en oversigt, der sammenligner engangsprodukter med flergangsalternativer. Denne sammenligning skal omfatte omkostninger, produktog barriereegenskaber, sterilisering, bortskaffelsesudgifter, levering, personale og andre serviceydelser, som dit vaskeri kan levere.

4. Når du har opnået en indledende tilslutning, skal du oprette et tværfagligt team.
5. Giv teamet (miljømedarbejdere, klinisk personale og beslutningstagere) en rundvisning i vaskeri- og pakkerummet.

6. Start en produktundersøgelse af et par ugers varighed. Nogle kan være modstandere af et program med flergangstekstiler, men lad dem prøve det.

7. Opstil en klar proces for gennemførelsen af den faktiske omlægning (en der sikrer, at den gamle beholdning af engangsprodukter bruges op osv.).

8. Fortsæt med at give personalet support og uddannelse, evaluer og mål resultaterne. 


\section{Afsnit 7 \\ Brug totalomkostningerne}

Totalomkostningerne (TCO) omfatter de omkostninger, der er forbundet med et produkt i hele dets levetid, fra det anskaffes, til det er slidt op. At træffe beslutninger baseret på TCO $i$ stedet for anskaffelsesprisen kan være til gavn for miljøet.

Når der vælges mellem tekstilprodukter er det billigste produkt ofte ikke det mest miljøvenlige. Men når et produkts livscyklusomkostninger beregnes, kan der være større overensstemmelse mellem miljøfordele og økonomi. Dette vil i særdeleshed gælde for mere holdbare tekstiler, som både sparer penge og har mindre miljøpåvirkninger, selv om de koster mere i indkøb. Valget mellem engangs- og flergangs tekstiler (se afsnit 6, side 28-29) kan også fremstå klarere efter en beregning af livscyklusomkostningerne eller totalomkostningerne (TCO), som det også kaldes.

TCO dækker de omkostninger, der er forbundet med et produkt i hele dets levetid, fra det anskaffes, til det er slidt op. TCO giver en ramme og et sprog til at beskrive og måle effekterne for bæredygtigheden på en måde, som indkøbscheferne umiddelbart forstår. Fx kan TCO anvendes sammen med en livscyklusanalyse (LCA) og lignende fremgangsmåder til at afdække (og kommunikere) muligheder for både at nedbringe omkostningerne og opnå bæredygtighed på områder som energi- og vandeffektivisering.

Brugen af TCO-overvejelser kræver viden om faktorer, der skal inkluderes i beregningerne, og et godt overblik over, hvordan produktet anvendes. For tekstiler til sundhedssektoren vil dette omfatte viden om:
- anskaffelsespris

- antal af anvendelser, før produktet er slidt op

- energi- og vandforbrug ved vask og tilknyttede omkostninger

- reparationsbehov og -omkostninger

- bortskaffelsesomkostninger

Du kan bruge TCO til at vælge mellem forskellige leverandører af tekstiler (se Rawicz Hospital-casen på side 28). Husk, at få leverandørerne til at dokumentere holdbarheden (antal af anvendelser før produktet er slidt op) for deres tekstiler, da dette er nøglefaktoren i en TCO. Inkluder en kontraktbestemmelse, der fastholder dem på dette niveau, hvis muligt.

De fleste store tekstilservicevirksomheder har udviklet TCO'er for at kunne minimere omkostningerne, og de kan eventuelt foretage disse beregninger for dig. Det samme kan gælde for statslige indkøbere som fx Sykehusinnkjøp HF i Norge. Men indkøbere på regionalt, kommunalt eller hospitalsniveau kan finde det for ressourcekrævende at udvikle TCO-beregnere for alle de produkter, de køber.

Til trods for at der findes en række værktøjer og tips, man kan støtte sig til, når man vurderer TCO'er, har der hidtil ikke været offentligt tilgængelige beregnere for TCO'er for tekstiler til sundhedssektoren. Du kan finde flere generelle informationer og værktøjer her: 


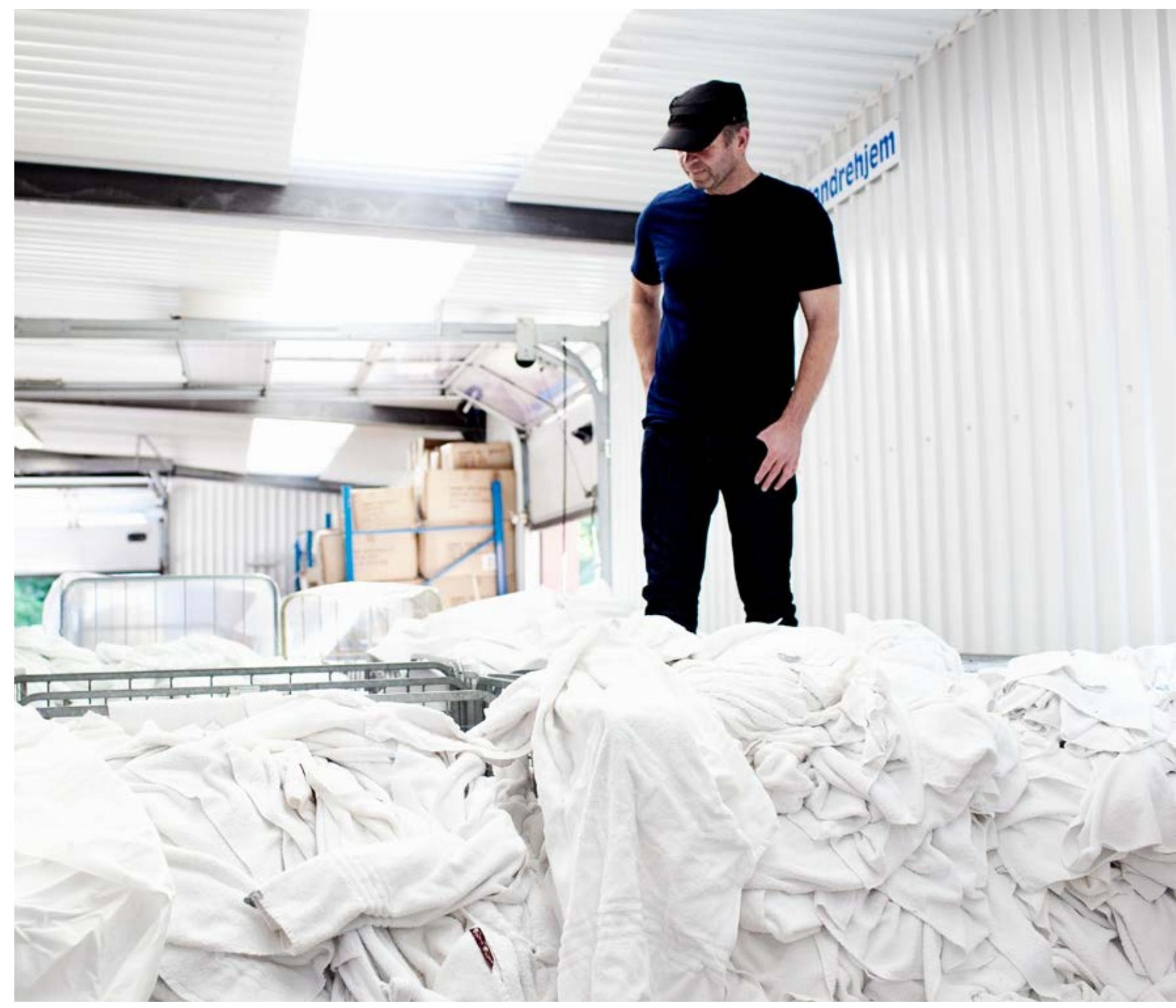

- Det danske Forum for Bæredygtige Indkøb - et nationalt netværk, som er et forum for vidensdeling, hvor indkøbere fra både offentlige og private virksomheder kan holde sig opdateret om best practice, metoder og værktøjer til grønne indkøb, herunder TCO-værktøjer
- Den Ansvarlige Indkøber - en hjemmeside, hvor indkøbere kan finde grønne kriterier, som kan kopieres direkte til tilbudsdokumenter, inden for en række produktområder og TCO-værktøjer for udvalgte produktområder

- BSR (Business for Social Responsibility) (engelsk) 
Afsnit 8

\section{Om guiden og netværket bag}

Denne guide er udviklet som en del af et initiativ under den nordiske handlingsplan

for bæredygtig mode og tekstil "Velklædt i et rent miljø" og finansieres af

Nordisk Ministerråd.

Den nordiske handlingsplan udpeger grønne offentlige indkøb som et vigtig indsatsområde. For det første fordi den offentlige sektor i sig selv er en stor tekstilforbruger - med en værdi på EUR 10 milliarder om året på EU-niveau ${ }^{13}$. For det andet kan grønne offentlige indkøb etablere markeder og processer, der kan have positive afsmittende effekter og inspirere private indkøbere til at følge trop.

Guiden er udviklet i samarbejde med et nordisk netværk af indkøbere i sundhedssektoren. Netværket er startet på initiativ af Miljøstyrelsen i Danmark på vegne af Nordisk Ministerråd. PlanMiljø ApS og TEM har bistået i processen, hjulpet med etableringen af netværket og udarbejdet guiden. Netværket består af følgende medlemmer:

Christian Leth Christensen, Region Midtjylland Anette Bjørn, Region Syddanmark

Susanne G. Sørensen, Region Nordjylland, Danmark Anya S. Midjord and Gudna á Rógvi Joensen, $L S H$ hospitalet, Færøerne Isa-Maria Bergman, Motiva, Finland

Outi Kalske, Hospitalsdistriktet for Sydvestfinland Karólína Guðmundsdóttir, Landspítali -

Háskólasjúkrahús, Island

Trude Ertresvåg, Sykehuspartner HF, Norge

Kine Stjern og Evy Pleym, Sykehusinnkjøp HF, Norge
Anna Chistiansson, Uphandlingsmyntigheten, Sverige Anja Ekstrand og Sofie Areborn, Region Skåne, Sverige Jonna Bjuhr Männer, Koncernkontoret Region Västra Götaland, Sverige

Christina Nukala-Pengel, Ålands Hälso- och Sjukvård, Åland

Rikke Dreyer og Lena Stenseng, Miljømærkning

Danmark

Weronika Rehnby, TEKO

Malin Hill, Berendsen AB

Hanne Selsholt Britz og Søren Vinzent, De Forenede

Dampvaskerier A/S

Fredrik Johansen, FOV Fabrics $A B$

Kate Riley, Oakdene Hollins

Rikke Fisher-Bogason og David Watson, PlanMiljø

Marie Pettersson og Daniel Eriksson, TEM

Birgitte Jørgensen Kjær og Anne-Mette Lysemose

Bendsen, Miljøstyrelsen

Spørgsmål om vejledningen og netværket kan sendes til Birgitte Jørgensen Kjær, Miljøstyrelsen: bjk@mst.dk

\footnotetext{
${ }^{13}$ http://susproc.jrc.ec.europa.eu/textiles/docs/141222\%20EU\%20GPP\%2OTextiles_Technical\%2Obackground\%2Oreport_Draft\%20 version\%201.pdf
} 
Nordiska Ministerråd

Ved Stranden 18

DK-1061 København K

www.norden.org

Denne guide henvender sig til indkøbere i den nordiske sundhedssektor, som er ansvarlige for indkøb af tekstilprodukter og -services, og bistår dem med at udvikle processer til at indføre passende og praktisk gennemførlige miljøkriterier i udbudsdokumenter. Indkøbere kan lære, hvilke aspekter af produktion og behandling af tekstiler der har den største betydning for miljøet, og hvordan disse kan behandles gennem kriterierne. De kan lære mere om miljømærkernes rolle i indkøbsprocessen og finde links til kriterier, der er klar til brug, og andre nyttige oplysninger fra nationale myndigheder. Guiden er udviklet i samarbejde med et nordisk netværk af indkøbere i sundhedssektoren som en del af et initiativ under den nordiske handlingsplan for bæredygtig mode og tekstil "Velklædt i et rent miljø". Det er finansieret af Nordisk Ministerråd. 